Pak. j. sci. ind. res. Ser. B: biol. sci. 201558 (2) 104-110

\title{
Concentration of Heavy Metals in Available Fish Species (Bain, Mastacembelus armatus; Taki, Channa punctatus and Bele, Glossogobius giuris) in the Turag River, Bangladesh
}

\author{
Rezuana Afrin ${ }^{\mathrm{a}}$, Md. Younus Mia*, Md. Aminul Ahsan ${ }^{\mathrm{b}}$ and Ahedul Akbor ${ }^{\mathrm{b}}$ \\ ${ }^{a}$ Department of Environmental Science and Resource Management, Mawlana Bhashani Science and \\ Technology University (MBSTU), Tangail, Bangladesh \\ ${ }^{b}$ Institute of National Analytical Research Service (INARS), Bangladesh Council of Scientific and Industrial \\ Research (BCSIR), Dhaka, Bangladesh
}

(received March 27, 2015; revised June 16, 2015; accepted June 19, 2015)

\begin{abstract}
This study was conducted to assess the concentration level of heavy metals in three available fish species (Bain, Mastacembelus armatus; Taki, Channa punctatus and Bele, Glossogobius giuris) of the Turag river, Bangladesh during the months from January to March, 2014. In case of bio-concentration of heavy metals in fish, the levels of $\mathrm{Pb}, \mathrm{Cd}, \mathrm{Cr}, \mathrm{Cu}$ and $\mathrm{Fe}$ ranged from $0.01-0.13 \mathrm{mg} / \mathrm{kg}, 0.001-0.02$ $\mathrm{mg} / \mathrm{kg}, 0.17-0.48 \mathrm{mg} / \mathrm{kg}, 0.30-0.74 \mathrm{mg} / \mathrm{kg}$ and $4.05-46.86 \mathrm{mg} / \mathrm{kg}$, respectively while $\mathrm{Hg}$ was below detection level. These values indicate that the heavy metals were concentrated in fish flesh at a higher level than water. The highest values of $\mathrm{Pb}, \mathrm{Cd}$ and $\mathrm{Cr}$ were found in Bain fish, $\mathrm{Fe}$ was found in Taki fish and $\mathrm{Cu}$ was found in Bele fish. Most of the heavy metals have crossed the permissible limits in fish, especially for the values of $\mathrm{Cr}, \mathrm{Cu}$ and $\mathrm{Fe}$. From the results of the present investigation, it can be concluded that the available fish species are harmful for their consumers.
\end{abstract}

Keywords: heavy metals, river fish, bio concentration, ecosystem

\section{Introduction}

Environmental problems related to heavy metals have a long history worldwide (Khan, 2008). Heavy metals can cause harm to human, animals and other organisms. As fish are often at the top of aquatic food webs and may concentrate large amounts of metals from the water and sediments, heavy metals can enter into human body very easily (Mansour and Sidky, 2002). But people commonly have no awareness about this problem and most of them have no knowledge about heavy metal exposure and its effects on health, especially in the developing countries.

The river Turag running by the side of the Dhaka City, the capital of Bangladesh, is one of the most polluted rivers in Bangladesh (DoE, 2003) and has been steadily experiencing complicated problems like pollution and encroachment that have almost suffocated the valuable lifelines of the city (Hossain, 2011). Main pollution sources of the Turag river water are various consumer goods industries and most of the industries discharge their effluents directly or indirectly into the Turag river without any treatment causing pollution of the surface water (Rahman et al., 2012).

*Author for correspondence; E-mail: mdmia1998@gmail.com
The river water is already polluted by various heavy metals discharging from industrial wastewaters and contamination of freshwater fish with heavy metals (HMs) is a recognised environmental problem (Staniskiene, 2006). Fish resources play an important role in the economy of Bangladesh, accounting for about 5\% of GDP and it is an important source of protein (MFL, 1998). Fisheries in Bangladesh contribute its role in mitigating animal protein shortage as well as providing jobs to millions of people. Fish provides $63 \%$ of the total animal protein supply and the per capita annual fish intake is about $15.04 \mathrm{~kg}$ (Sarder, 2007). As fish is an important natural resource and good food source, it is very much needed to know the concentration levels of harmful heavy metals in fish living in polluted water. The present study was conducted by considering this reason for leading a safer and better life. As Turag river water is very much polluted, only the fish species that can survive in polluted water and in low DO level of water are available here. In the present study, 3 available fish species i.e., M. armatus (Bain), C. punctatus (Taki), and G. giuris (Bele) were collected from Turag river and analysed for some heavy metals to know their concentra-tions in the muscles of those fish species. 


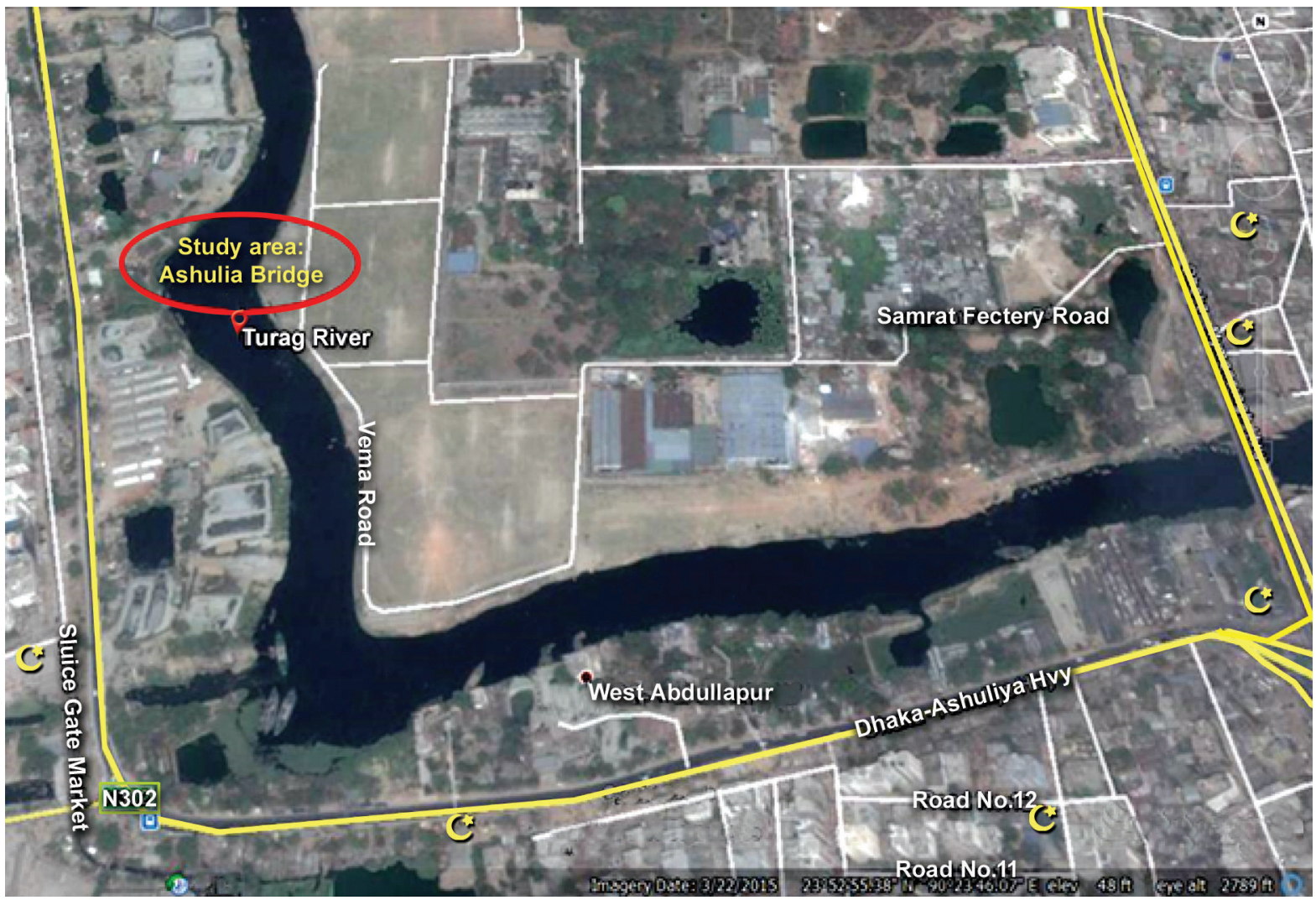

Fig. 1. Map showing the Turag River and the study area.

\section{Materials and Methods}

Sample collection. Samples of three fish from each of the 3 available species (Mastacembelus armatus, Channa punctatus, and Glossogobius giuris) were collected from Ashulia bridge area (Table 1) and kept them in an ice-box.

Fish samples were collected for 3 times in January, February and March, 2014. After collection, the samples were preserved and labeled properly and kept at $-20{ }^{\circ} \mathrm{C}$. Then the fish samples were analysed for heavy metals $(\mathrm{Pb}, \mathrm{Cd}, \mathrm{Cu}, \mathrm{Cr}, \mathrm{Hg}$ and $\mathrm{Fe})$ at Institute of National Analytical Research and Service (INARS), BCSIR Laboratories, Dhaka, Bangladesh.

Table 1. Fish specimens (3 specimens for each species) recollected from Turag river in Bangladesh

\begin{tabular}{lll}
\hline \hline S. No. & Local name & Scientific name \\
\hline Species 1 & Bain & Mastacembelus armatus \\
Species 2 & Taki & Channa punctatus \\
Species 3 & Bele & Glossogobius giuris \\
\hline \hline
\end{tabular}

Sample analysis. Sample preparation. For heavy metal analysis, ashing process was followed for fish samples except Hg. At first the fish were gutted and flesh was separated. The flesh was put in a watch glass for each sample. Then they were weighted (above $10 \mathrm{~g}$ for each sample) properly and taken in dry beakers. The beakers were put in furnace at $100^{\circ} \mathrm{C}$ for $1 \mathrm{~h}$, then at $200^{\circ} \mathrm{C}$ for $1 \mathrm{~h}$, then at $300{ }^{\circ} \mathrm{C}$ for $1 \mathrm{~h}$ and then at $450{ }^{\circ} \mathrm{C}$ for $4-5 \mathrm{~h}$ until the samples became totally dry or ash. After drying in furnace, concentrated $\mathrm{HNO}_{3}$ and distilled water (1:1) were added in the beakers to make them wet. Then the beakers were put in hot-plate and evaporated until they were dry again. After that the beakers were kept in the furnace at $550{ }^{\circ} \mathrm{C}$ for $5-6 \mathrm{~h}$. After taking out from the furnace, $20 \mathrm{~mL} \mathrm{HNO}_{3}$ was put into each beaker. Then they were put on the hot-plate by keeping watch glass on each beaker and heated until boiling.

After boiling the beakers were taken out from the hotplate. Then the samples were taken in $50 \mathrm{~mL}$ volumetric flasks and filled with distilled water up to the mark. At last they were filtered and preserved in labeled containers for each sample. 
For $\mathrm{Hg}$ analysis in fish, acid digestion process was followed. At first the weight (above $10 \mathrm{~g}$ for each sample) of the fish samples were taken properly and then $20 \mathrm{~mL} \mathrm{HNO}_{3}$ and $10 \mathrm{~mL} \mathrm{HClO}_{4}$ were added to each sample in beakers. The beakers were boiled on the hotplate until the samples became totally colourless. Then they were taken in $50 \mathrm{~mL}$ volumetric flasks and filled with distilled water up to the mark. After that the samples were filtered properly and kept in separate containers (APHA, 1998).

Instrumental analysis. The $\mathrm{Pb}, \mathrm{Cd}$ and $\mathrm{Cr}$ concentrations of fish samples were analysed using Zeeman Atomic Absorption Spectrometer (Model: Varian, AA 240Z and Method: APHA 3113.B). The prepared samples were taken in vials and put in specific positions of Atomic Absorption Spectrometer (AAS) (AA 240 $\mathrm{Z}$ ). Hg concentration of water samples was analysed using Cold Vapor Hydride Generation Atomic Absorption Spectrometer (Model: Varian, AA 220FS and Method: APHA 3112.C). $\mathrm{Cu}$ and Fe concentrations of water samples were analysed using Flame Atomic Absorption Spectrometer (Model: Varian, AA 240FS and Method: APHA 3111.B) (APHA, 1998). The recovery ranges for each parameter were $100 \% \pm 20 \%$. The detection limit for $\mathrm{Fe}, \mathrm{Cu}, \mathrm{Cr}, \mathrm{Cd}, \mathrm{Hg}$ and $\mathrm{Pb}$ were 0.027, 0.01, 0.0035, 0.00012, 0.00019 and $0.003 \mathrm{ppm}$, respectively. For lower concentration of heavy metals, the samples were pre-concentrated and for higher concentration of heavy metals, the samples were diluted. The standards used for $\mathrm{Pb}, \mathrm{Cd}, \mathrm{Cr}, \mathrm{Cu}, \mathrm{Hg}$ and $\mathrm{Fe}$ were $30 \mathrm{ppb}, 2 \mathrm{ppb}, 10 \mathrm{ppb}, 10 \mathrm{ppb}, 5 \mathrm{ppm}$ and $1 \mathrm{ppm}$, respectively.

\section{Results and Discussion}

Heavy metals in fish. Lead $(\boldsymbol{P b})$. The highest value $(0.13 \mathrm{mg} / \mathrm{kg})$ of $\mathrm{Pb}$ was observed in species 3 in January and the lowest $(0.01 \mathrm{mg} / \mathrm{kg})$ was observed in species
2 in January (Table 2). The order of $\mathrm{Pb}$ accumulation in fish is kidney> gill $>$ liver $>$ muscle (Abdel-Baki, 2011). Afrin et al. (2014) found the highest value of $\mathrm{Pb}$ in Ashulia bridge area of the Turag river water as 0.005 $\mathrm{mg} / \mathrm{L}$ in March, 2014.

Lead $(\mathrm{Pb})$ can affect every organ and system in the body (CHSR, 2009). The symptoms of acute lead poisoning are headache, irritability, abdominal pain and various symptoms related to the nervous system. Longterm lead exposure may also give rise to kidney damage and long-term low-level lead exposure in children may lead to diminished intellectual capacity. Experiment suggests a weighted mean decrease in IQ of 2 points for a $0.48 \mu \mathrm{mol} / \mathrm{L}(10 \mu \mathrm{g} / \mathrm{dL})$ increase in blood lead level (Jarup, 2003).

Ahmad et al. (2010) found the highest level of $\mathrm{Pb}$ in chapila (Gonialosa manmina), $(13.52 \mathrm{mg} / \mathrm{kg}$ ) during monsoon and the lowest in tatkeni, Cirrhinus reba $(8.03$ $\mathrm{mg} / \mathrm{kg}$ ) during pre-monsoon in the Buriganga river. Ahmed et al. (2009b) studied the heavy metal concentration in fish from the Dhaleswari river, Bangladesh and found the seasonal variation of $\mathrm{Pb}$ from 7.03 to $12.18 \mathrm{mg} / \mathrm{kg}$. Ahmed et al. (2009a) investigated the heavy metal concentration in fish and oyster from the Shitalakhya river, Bangladesh and found seasonal variation of $\mathrm{Pb}$ ranging from 9.16 to $13.09 \mathrm{mg} / \mathrm{kg}$. These values differ from the present study because the values of $\mathrm{Pb}$ were observed in the whole body in the previous results. But it was observed only in the muscle or flesh of fish in the present study, where the bio-accumulation level is very low.

According to Indrajith et al. (2008), concentration of $\mathrm{Pb}$ ranged from $0.01-0.08 \mathrm{mg} / \mathrm{kg}$ in E. suratensis and $0.004-0.06 \mathrm{mg} / \mathrm{kg}$ in A. commersoni in Negombo estuary, Srilanka. Nwani et al. (2010) studied the mean concentration of $\mathrm{Pb}$ in the muscle of the six fish species which

Table 2. Concentrations of heavy metals ( $\mathrm{mg} / \mathrm{kg}$ ) in fish (flesh) samples

\begin{tabular}{|c|c|c|c|c|c|c|c|c|c|}
\hline \multirow[t]{3}{*}{ Heavy metals } & \multicolumn{3}{|c|}{ Species 1} & \multicolumn{3}{|c|}{ Species 2} & \multicolumn{3}{|c|}{ Species 3} \\
\hline & Jan & Feb & Mar & Jan & Feb & Mar & Jan & Feb & Mar \\
\hline & 2014 & 2014 & 2014 & 2014 & 2014 & 2014 & 2014 & 2014 & 2014 \\
\hline $\mathrm{Pb}$ & 0.03 & 0.1 & 0.03 & 0.01 & 0.03 & 0.06 & 0.13 & 0.02 & 0.03 \\
\hline $\mathrm{Cd}$ & 0.003 & 0.02 & 0.005 & 0.001 & 0.01 & 0.007 & 0.003 & 0.002 & 0.003 \\
\hline $\mathrm{Cr}$ & 0.48 & 0.36 & 0.27 & 0.27 & 0.17 & 0.30 & 0.42 & 0.30 & 0.43 \\
\hline $\mathrm{Cu}$ & 0.61 & 0.74 & 0.72 & 0.43 & 0.30 & 0.60 & 0.76 & 0.48 & 0.63 \\
\hline $\mathrm{Hg}$ & N. D. & N. D. & N. D. & N. D. & N. D. & N. D. & N. D. & N. D. & N. D. \\
\hline $\mathrm{Fe}$ & 7.08 & 5.83 & 8.41 & 4.85 & 8.46 & 46.86 & 8.03 & 4.05 & 5.70 \\
\hline
\end{tabular}

$*$ N. D. $=$ Not Detectable 
varied from minimum of $0.10 \pm 0.01 \mathrm{mg} / \mathrm{kg}$ to a maximum value of $0.31 \pm 0.01 \mathrm{mg} / \mathrm{kg}$ in lotic freshwater ecosystem at Afikpo, Nigeria. Daka et al. (2008) obtained 0.01$0.06 \mathrm{mg} / \mathrm{kg}$ for $\mathrm{Pb}$ in fish species from Azuabie Creek in the Bonny Estuary, Nigeria. Oguzie (2003) reported $\mathrm{Pb}$ concentration of $0.007-0.03 \mathrm{mg} / \mathrm{kg}$ in fishes from Ikpoba River Nigeria. Burgera and Gochfeld (2005) found $\mathrm{Pb}$ ranged from 0.04 to $0.12 \mathrm{mg} / \mathrm{kg}$ in some marine fish of New Jersey, USA. The previous values are mostly similar to the present study.

Cadmium (Cd). Here, the highest value $(0.02 \mathrm{mg} / \mathrm{kg})$ of $\mathrm{Cd}$ was observed in species 1 in February and the lowest $(0.001 \mathrm{mg} / \mathrm{kg})$ was observed in species 2 in January (Table 2). The order of Cd accumulation in fish is liver $>$ gill $>$ kidney $>$ muscle (Abdel-Baki, 2011). Afrin et al. (2014) found the highest value of $\mathrm{Cd}$ in Ashulia bridge area of the Turag river water as 0.00003 $\mathrm{mg} / \mathrm{L}$ in January, 2014.

Cadmium and their compounds are known human carcinogens. Ingesting very high levels severely irritates the stomach, leading to vomiting and diarrhoea. Longterm exposure to lower levels leads to a buildup in the kidneys and possible kidney disease, lung damage, and fragile bones (CHSR, 2009).

According to Ahmad et al. (2010), Cd concentration was the highest in batashi, Neotropius atherinoides $(1.25 \mathrm{mg} / \mathrm{kg})$ during monsoon and the lowest in tatkeni, Cirrhinus reba $(0.73 \mathrm{mg} / \mathrm{kg})$ during post-monsoon in Buriganga river. Ahmed et al. (2009b) studied the heavy metal concentration in fish from the Dhaleswari river, Bangladesh and found the seasonal variation of $\mathrm{Cd}$ $(0.52-0.8 \mathrm{mg} / \mathrm{kg})$. Sharif et al. (1993) studied the heavy metal concentration in $T$. vagina and found the concentration of $\mathrm{Cd}$ as $0.11 \pm 0.00 \mathrm{mg} / \mathrm{kg}$ (dry weight basis). All these values differ from the present study due to different accumulation levels of $\mathrm{Cd}$ in different organs of fish and also for abundance of $\mathrm{Cd}$ enriched pollutants in water.

According to Indrajith et al. (2008), concentration of Cd ranged from 0.002 to $0.048 \mathrm{mg} / \mathrm{kg}$ in E. suratensis and $0.001-0.030 \mathrm{mg} / \mathrm{kg}$ in $A$. commersoni in Negombo estuary, Srilanka. Burgera and Gochfeld (2005) found $\mathrm{Cd}$ ranged from 0.0001 to $0.01 \mathrm{mg} / \mathrm{kg}$ in some marine fish of New Jersey, USA. The values of the previous study are mostly similar to the present study.

Chromium (Cr). The highest value $(0.48 \mathrm{mg} / \mathrm{kg})$ of $\mathrm{Cr}$ was observed in species 1 in January and the lowest
$(0.17 \mathrm{mg} / \mathrm{kg})$ was observed in species 2 in February (Table 2). The order of $\mathrm{Cr}$ accumulation in fish is kidney $>$ gill $>$ liver $>$ muscle (Abdel-Baki, 2011). Afrin et al. (2014) found the highest value of $\mathrm{Cr}$ in Ashulia bridge area of the Turag river water as $0.024 \mathrm{mg} / \mathrm{L}$ in March, 2014.

Chromium (VI) compounds are toxins and known human carcinogens, whereas breathing high levels of chromium (III) can cause irritation to the lining of the nose, nose ulcers, runny nose, and breathing problems; such as asthma, cough, shortness of breath, or wheezing. Skin contact can cause skin ulcers. Allergic reactions consisting of severe redness and swelling of the skin have been noted. Long term exposure can cause damage to liver, kidney circulatory and nerve tissues, as well as skin irritation (CHSR, 2009).

According to Ahmad et al. (2010), Cr concentration was the highest in chapila, Gonialosa manmina $(7.38 \mathrm{mg} / \mathrm{kg})$ during monsoon and the lowest in tengra, Mystus tengara $(5.27 \mathrm{mg} / \mathrm{kg})$ during monsoon in the Buriganga river. Ahmed et al. (2009b) studied the heavy metal concentration in fish from the Dhaleswari river, Bangladesh and found the seasonal variation of $\mathrm{Cr}(9.38-19.65 \mathrm{mg} / \mathrm{kg})$. Ahmed et al. (2009a) investigated the heavy metal concentration in fish and oyster from the Shitalakhya river, Bangladesh and found seasonal variation of $\mathrm{Cr}$ ranged from 8.12 to $9.07 \mathrm{mg} / \mathrm{kg}$. All these values differ from the present study due to different accumulation levels of $\mathrm{Cr}$ in different organs of fish and also for abundance of $\mathrm{Cr}$ enriched pollutants from tannery industries in river water.

According to Indrajith et al. (2008), concentration of $\mathrm{Cr}$ ranged from $0.02-0.28 \mathrm{mg} / \mathrm{kg}$ in E. suratensis and 0.01 $0.24 \mathrm{mg} / \mathrm{kg}$ in A. commersoni in Negombo estuary, Srilanka. Nwani et al. (2010) studied the mean concentration of Cr in the muscles of fish species which varied from minimum of $0.28 \pm 0.04 \mathrm{mg} / \mathrm{kg}$ in M. tapirus and C. anguillaris to a maximum of $0.66 \pm 0.04 \mathrm{mg} / \mathrm{kg}$ in C. nigrodigitatus and T. zillii in lotic freshwater ecosystem at Afikpo, Nigeria. These values are in line to the present study.

Copper (Cu). Here, the highest value $(0.74 \mathrm{mg} / \mathrm{kg})$ of $\mathrm{Cu}$ was observed in species 1 in February and the lowest (0.30 $\mathrm{mg} / \mathrm{kg}$ ) was observed in species 2 in February (Table 2). The order of $\mathrm{Cu}$ accumulation in fish is liver $>$ kidney $>$ gill $>$ muscle (Abdel-Baki, 2011). Afrin et al. (2014) found the highest value of $\mathrm{Cu}$ in Ashulia bridge area of the Turag river water as $0.09 \mathrm{mg} / \mathrm{L}$ in March, 2014. 
$\mathrm{Cu}$ is one of the essential elements for humans and the adult daily requirement is about $2.0 \mathrm{mg}$ (De, 2005). But long term exposure to $\mathrm{Cu}$ has deleterious effects on human health. In case reports of humans intentionally or accidentally ingesting high concentrations of copper salts (doses usually not known but reported to be 20-70 g copper), a progression of symptoms was observed including abdominal pain, headache, nausea, dizziness, vomiting and diarrhoea, tachycardia, respiratory difficulty, hemolytic anemia, massive gastrointestinal bleeding, liver and kidney failure, and death (Stern et al., 2007).

Ahmed et al. (2009b) studied the heavy metal concentration in fish from the Dhaleswari river, Bangladesh and found the seasonal variation of $\mathrm{Cu}(7.55-11.50 \mathrm{mg} / \mathrm{kg})$. Ahmad et al. (2010) studied that $\mathrm{Cu}$ level was the highest (6.34 $\mathrm{mg} / \mathrm{kg}$ ) in chapila, Gonialosa manmina during postmonsoon and the lowest in tatkeni, Cirrhinus reba (3.36 $\mathrm{mg} / \mathrm{kg}$ ) during the same time in the Buriganga river. Ahmed et al. (2009a) investigated the heavy metal concentration in fish and oyster from the Shitalakhya river, Bangladesh and found seasonal variation of $\mathrm{Cu}$ ranged from 5.47-8.19 $\mathrm{mg} / \mathrm{kg}$. All these values differ from the present study due to different accumulation levels of $\mathrm{Cu}$ in different organs of fish and also for abundance of $\mathrm{Cu}$ enriched pollutants in water.

According to Indrajith et al. (2008), concentration of $\mathrm{Cu}$ ranged from 0.02 to $0.37 \mathrm{mg} / \mathrm{kg}$ in E. suratensis and 0.01$0.25 \mathrm{mg} / \mathrm{kg}$ in A. commersoni in Negombo estuary, Srilanka. Nwani et al. (2010) studied the mean concentration of $\mathrm{Cu}$ in the muscles of fish species which varied from minimum of $0.56 \pm 0.03 \mathrm{mg} / \mathrm{kg}$ in C. anguillaris to a maximum of $1.33 \pm 0.06 \mathrm{mg} / \mathrm{kg}$ in T. zillii in lotic freshwater ecosystem at Afikpo, Nigeria. These values are mostly similar to the present study.

Mercury $(\mathbf{H g})$. Here, the level of concentration of $\mathrm{Hg}$ was not detectable for all fish species (Table 2) because there was no or a very little source of $\mathrm{Hg}$ containing pollutants in the Turag water. Normally the order of $\mathrm{Hg}$ accumulation in fish is kidney $>$ liver $>$ muscle $>$ gill (Abdel-Baki, 2011). Afrin et al. (2014) found $\mathrm{Hg}$ as not detectable in Ashulia bridge area of the Turag river water.

Mercuric chloride and methyl mercury are possible human carcinogens. The nervous system is very sensitive to all forms of mercury. Exposure to high levels can permanently damage the brain, kidneys, and developing fetuses (CHSR, 2009). A high dietary intake of mercury from consumption of fish has been hypothesised to increase the risk of coronary heart disease (Jarup, 2003). According to Indrajith et al. (2008), concentration of $\mathrm{Hg}$ ranged from 0.03 to $0.33 \mathrm{mg} / \mathrm{kg}$ in E. suratensis and $0.04-0.26 \mathrm{mg} / \mathrm{kg}$ in A. commersoni in Negombo estuary, Srilanka. All these values differ from the present study due to different accumulation levels of $\mathrm{Hg}$ in different organs of fish and also for abundance of $\mathrm{Hg}$ enriched pollutants in water.

Iron $(\boldsymbol{F e})$. The highest value $(46.86 \mathrm{mg} / \mathrm{kg})$ of $\mathrm{Fe}$ was observed in species 2 in March and the lowest (4.05 $\mathrm{mg} / \mathrm{kg}$ ) was observed in species 3 in February (Table 2). Afrin et al. (2014) found the highest value of $\mathrm{Fe}$ in Ashulia bridge area of the Turag river water as 6.33 $\mathrm{mg} / \mathrm{L}$ in March, 2014.

Iron is an essential element in human nutrition. Estimates of the minimum daily requirement for iron depend on age, sex, physiological status, and iron bioavailability and range from about 10 to $50 \mathrm{mg} /$ day. The average lethal dose of iron is $200-250 \mathrm{mg} / \mathrm{kg}$ of body weight, but death has occurred following the ingestion of doses as low as $40 \mathrm{mg} / \mathrm{kg}$ of body weight. Adults have often taken iron supplements for extended periods without deleterious effects and an intake of $0.4-1 \mathrm{mg} / \mathrm{kg}$ of body weight per day is unlikely to cause adverse effects in healthy persons (WHO, 2003).

Nwani et al. (2010) studied the concentration of Fe in the muscles $(\mathrm{mg} / \mathrm{kg})$ of the fish species which varied from minimum of $186.00 \pm 0.07 \mathrm{mg} / \mathrm{kg}$ in M. tapirus and C. anguillaris to maximum of $443.20 \pm 0.08 \mathrm{mg} / \mathrm{kg}$ in C. nigrodigitatus and T. zillii, respectively. These values differ from the present study due to different accumulation levels of Fe in different organs of fish and also for abundance of $\mathrm{Fe}$ enriched pollutants in water.

\section{Conclusion}

According to this study, heavy metals can be concentrated in fish species. The study observed a great amount of heavy metals especially $\mathrm{Cr}(0.17-0.48 \mathrm{mg} / \mathrm{kg}), \mathrm{Cu}$ $(0.30-0.74 \mathrm{mg} / \mathrm{kg})$ and $\mathrm{Fe}(4.05-46.86 \mathrm{mg} / \mathrm{kg})$ in fish flesh or muscle that can be lethal to fish, humans and other organisms. Concentrations of $\mathrm{Pb}(0.0-0.13 \mathrm{mg} / \mathrm{kg})$ and $\mathrm{Cd}(0.001-0.02 \mathrm{mg} / \mathrm{kg})$ were very low in fish and $\mathrm{Hg}$ was below the detection level. According to the previous studies, fish flesh or muscle has the lowest level of bio-concentration. So, the concentration levels of heavy metals are comparatively low in the present study. The concentration levels of $\mathrm{Cd}, \mathrm{Cr}$ and $\mathrm{Cu}$ were highest in bain, Mastacembelus armatus (species 1). 
Concentration of $\mathrm{Pb}$ was highest in bele, Glossogobius giuris (species 3) and Fe in taki, Channa punctatus (species 2). Highest bio-concentration levels of $\mathrm{Pb}$ and $\mathrm{Cr}$ were observed in January, $\mathrm{Cd}$ and $\mathrm{Cu}$ were observed in February and Fe in March.

In the present investigation, some heavy metals concentrations $(\mathrm{Cr}, \mathrm{Cu}, \mathrm{Fe})$ are higher than the safe recommended values, which suggest that the Turag river is partly a heavy metal polluted river and the water and fish are not fully safe for human health and ecosystem. Again lower concentration of heavy metals $(\mathrm{Pb}, \mathrm{Cd})$ can be harmful to human health and organism in case of long term exposure.

\section{References}

Abdel-Baki, A.S., Dkhil, M.A., Al-Quraishy, S. 2011. Bioaccumulation of some heavy metals in tilapia fish relevant to their concentration in water and sediment of Wadi Hanifah, Saudi Arabia. African Journal of Biotechnology, 10: 2541-2547.

Afrin, R., Mia, M.Y., Akter, S. 2014. Investigation of heavy metals $(\mathrm{Pb}, \mathrm{Cd}, \mathrm{Cr}, \mathrm{Cu}, \mathrm{Hg}$ and $\mathrm{Fe}$ ) of the Turag River in Bangladesh. Journal of Environmental Science and Natural Resources, 7: 133-136.

Ahmad, M.K., Islam, S., Rahman, S., Haque, M.R., Islam, M.M. 2010. Heavy metals in water, sediment and some fishes of Buriganga River, Bangladesh. International Journal of Environmental Research, 4: 321-332.

Ahmed, M.K., Bhowmik, A.C., Rahman, S., Haque, M.R., Hasan, M.M., Hasan, A.A. 2009a. Heavy metal concentrations in water, sediments and their bio-accumulations in fishes and oyster in Shitalakhya River. Terres. Aqua. Environ. Toxicol. (in press).

Ahmed, M.K., Ahamed, S., Rahman, S., Haque, M.R., Islam, M.M. 2009b. Heavy metal concentrations in water, sediments and their bio-accumulations in fishes and oyster in Dhaleswari River. Asian Journal of Water, Environment and Pollution (in press).

APHA, 1998. Standard Methods for the Examination of Water and Wastewater. $22^{\text {nd }}$ edition, Published by American Public Health Association (APHA), American Water Works Association, Water Environment Federation, USA.

Burgera, J., Gochfeld, M. 2005. Heavy metals in commercial fish in New Jersey. Environmental Research, 99: 403-412.

CHSR, 2009. Human Health Effects of Heavy Metals. Edited, designed, and printed by Center for Hazardous
Substance Research. (CHSR), Kansas State University, as part of the Technical Assistance to Brownfields Communities (TAB) Program. 15: 1-6.

Daka, E.R., Ekeh, C.A., Moslen, M. 2008. Cadmium and lead levels in some fish species from Azuabie creek in the Bonny Estuary, Nigeria. African Journal of Biotechnology, 7: 63-64.

De, A. K. 2005. Environmental Chemistry. pp. 189$242,5^{\text {th }}$ edition, New Age International Publishers, New Delhi, India.

DoE, 2003. Water Quality Data of Rivers Buriganga, Meghna, Balu, Shitalakhya, Jamuna (1991-2000). Department of Environment, Dhaka, Bangladesh.

Hossain, M. S. 2011. Time to save the Turag from pollution. The Daily Star (January 8).

Indrajith, H.A.R., Pathiratne, K.A.S., Pathiratne, A. 2008. Heavy metal levels in two food fish species from Negombo estuary, Sri Lanka: Relationships with the body size. Sri Lanka Journal of Aquatic Sciences, 13: 63-81.

Jarup, L. 2003. Hazards of heavy metal contamination. Department of Epidemiology and Public Health, Imperial College, London, UK. British Medical Bulletin, 68: 167-182.

Khan, M. K. A. 2008. Environmental Pollution around Dhaka EPZ and its Impact on Soil, Water and Ecology, an unpublished M. Sc. Thesis, Department of Geology, University of Dhaka, Bangladesh.

Mansour, S.A., Sidky, M.M. 2002. Ecotoxicological studies: Heavy metals contaminating water and fish from Fayoum Governorate, Egypt. Food Chemistry, 78: 15-22.

MFL, 1998. National Fish Policy. Ministry of Fisheries and Livestock, Bangladesh.

Nwani, C.D., Nwachi, D.A., Okogwu, O.I., Ude, E.F., Odoh, G.E. 2010. Heavy metals in fish species from lotic freshwater ecosystem at Afikpo, Nigeria. Journal of Environmental Biology, 31: 595-601.

Oguzie, F.A. 2003. Heavy metals in fish, water and effluents of lower Ikpoba River Benin City. Pakistan Journal of Scientific and Industrial Research, 46: 156-160.

Rahman, A.K.M.L., Islam, M., Hossain, M.Z., Ahsan, M.A. 2012. Study of the seasonal variations in Turag river water quality parameters. African Journal of Pure and Applied Chemistry, 6: 144-148.

Sarder, R. 2007. Freshwater fish seed resources in Bangladesh. In: Assessment of Freshwater Fish Seed Resources for Sustainable Aquaculture. M.G. Bondad- Reantaso (ed.), FAO Fisheries Technical 
Paper. No. 501, 628 pp., FAO, Rome.

Sharif, A.K.M., Alamgir, M., Mustafa, A. I., Hossain, M.A., Amin, M.N. 1993. Trace element concentration in ten species of freshwater fish in Bangladesh. Science of the Total Environment, 138: 117-126.

Staniskiene, B., Matusevicius, P., Budreckiene, R., Skibniewska, K.A. 2006. Distribution of heavy metals in tissues of freshwater fish in lithuania. Polish Journal of Environmental Studies, 15: 585-591.

Stern, B.R., Solioz, M., Krewski, D., Aggett, P., Aw, T., Baker, S., Crump, K., Dourson, M., Haber, L.,
Hertzberg, R., Keen, C., Meek, B., Rudenko, L., Schoeny, R., Slob, W., Starr, T. 2007. Copper and human health: Biochemistry, genetics, and strategies for modeling dose-response relationships. Journal of Toxicology and Environmental Health, Part B. 10: $157-222$.

WHO, 2003. Iron in Drinking-water. Originally published. In: Guidelines for Drinking-Water Quality, $2^{\text {nd }}$ edition, vol. 2. Health criteria and other supporting information. World Health Organization, Geneva, Switzerland. 